\title{
Food web dynamics in the ocean. I. Best-estimates of flow networks using inverse methods
}

\author{
Alain F. Vézina*, Trevor Platt \\ Bediord Institute of Oceanography, Dartmouth, Nova Scotia, Canada B2Y 4A2
}

\begin{abstract}
We describe the application of inverse methods to the estimation of food web fluxes in undersampled ocean environments. The general objective is to deduce the flow networks that conserve mass, satisfy basic biological constraints, and are compatible with the observed structure of the food web. Given inevitable gaps in the observational data, a number of different networks will fit these requirements. In this paper, we estimate the simplest possible flow structure, that is, the network that minimizes (1) the sum total of the rate constants that relate flux to stock and (2) the differences among the constants. We present a general framework for the application of the inverse algorithm: (1) a linear compartmental model of the oceanic food web that initially includes all the possible inter-compartmental fluxes, and (2) a set of constraints on the flow estimates that reflect contemporary knowledge of the limits and efficiencies of ecophysiological processes. The methodology is applied to detailed observations of food web structure and dynamics in 2 areas off the English coast. The inverse solutions are discussed in terms of current concepts of the role of the microbial loop in the pelagic marine ecosystem.
\end{abstract}

\section{INTRODUCTION}

An important objective of contemporary biological oceanography is to project the response of ocean ecosystems to continuing anthropogenic stresses (National Science Foundation 1977, Intergovernmental Oceanographic Commission 1984). Of particular interest recently is the role of the ocean biota in the regulation of rising atmospheric $\mathrm{CO}_{2}$ levels (US Global Ocean Flux Study 1986). There is increasing evidence that the net loss of $\mathrm{C}$ from the surface waters that ultimately drives the air-sea $\mathrm{CO}_{2}$ flux depends on the structure and dynamics of the planktonic food web. Non-linear effects of particle concentration on sinking losses (Vézina \& Platt 1987), the size structure of the community (Coale \& Bruland 1987, Vézina \& Platt 1987), the complexity of food web links (Frost 1984, Goldman \& Caron 1985), and the activity of sea microbes (Ducklow et al. 1986, Pomeroy \& Deibel 1986) may, alternatively or in concert, determine particulate losses from the trophogenic zone. Comparative analyses of the dynamics of food webs in different marine environ-

\footnotetext{
- Atomic Energy of Canada Limited, Research Company, Chalk River Nuclear Laboratories, Chalk River, Ontario, Canada K0J $1 \mathrm{~J} 0$
}

ments are a pre-requisite to a deeper understanding of the regulation of particulate fluxes (US Global Ocean Flux Study 1986) and other ecosystem-level processes (Leggett et al. 1985).

The most widely used representation of food web structure and dynamics is the compartmental model (Platt et al. 1981). As new information comes to light, our basic model of the marine food web has become increasingly complex, now including microbial and detrital pathways (Pomeroy 1974). This increase in knowledge has so far outpaced our capacity to make all the necessary measurements at any one site (Leggett et al. 1985). Observational information allows only gross oversimplifications of the dynamics of local food webs. The alternative is to develop numerical (Steele \& Frost 1977, Steele \& Henderson 1981, Pace et al. 1984), or flow analysis (Fasham 1985) models of food webs that can be as comprehensive as required. These models, however, emphasize prior knowledge of ecological processes at the expense of site-specific information. There is an urgent need to apply techniques that merge the information contained in the site-specific empirical data with the insights of theoretical models to yield comparable and reasonably exhaustive descriptions of food web fluxes in different marine ecosystems.

We investigated the use of inverse methods, 
borrowed from the physical sciences (Parker 1977, Wunsch 1978), to achieve this objective. The inverse formalism can process eclectic data on food web structure and dynamics (standing stocks of different materials, flux rate measurements, energetic and physiological constraints, etc.) and generate estimates of the flows of several materials (e.g. C and N) simultaneously. The solution process ensures internal consistency, allows for uncertainties and redundancies in the data, and forces the flow networks to meet explicit operational requirements to make inter-site comparisons possible. In this paper, we describe an inverse procedure that recovers the simplest possible flow networks that are compatible with the data; these networks exclude any structure that is not required to conserve mass or satisfy basic biological constraints. In a follow-up paper (Vézina \& Platt unpubl.), we will demonstrate the use of linear programming techniques to derive flow configurations that minimize or maximize certain properties of the networks, for example the total heterotrophic energy flux generated per unit of primary production or the flux through the microbial loop pathways. We will develop a general framework for the application of these techniques to food web data and illustrate the techniques with 2 data sets from the English coast (Celtic Sea and Western Channel Approaches).

\section{BASIC PRINCIPLES}

\section{The inverse problem in food web research}

Empirical budgets for food webs are generally constructed from the bottom up, with prior estimates of the flows combined to form a network whose state of balance is left uncontrolled. As a rule, direct estimates of most of the flows in a reasonably complex food web are not available. Under these conditions, the flow of materials through the system cannot be uniquely specified. It seems more rigorous then to use the requirement that the flows balance (in the sense that the inputs are equal to the sum of the outputs and the rate of change in the standing stocks) for deduction of the flow networks. This is an inverse problem: values of unknown parameters are deduced from a set of observations and a model of the system (Parker 1977). Similar problems are encountered, for example, in physical oceanography where the flow field is recovered from the spatial distribution of tracers (Wunsch 1978), and in geophysics where the structure of the earth is deduced from seismic wave propagation (Wiggins 1972). As in food web research, investigators in these fields face the fundamental limitation that the number of independent observations they can make is usually far less than the number of parameters they need to know to describe ocean circulation or earth structure (Parker 1977, Wunsch 1978, Wunsch \& Minster 1982). Inverse methods provide the machinery to generate, examine and compare a number of solutions to research questions that are compatible with the available data.

The inversion procedure starts with a model of the system, in our case a compartmental model of the food web. Normally, the model is used in numerical experiments to project the behavior of the state variables (i.e. standing stocks) from known parameter values and initial conditions. The inverse method is simply the reverse of that procedure: observations of the state variables are used to estimate the parameters. In this sense, inverse methods have strong affinities with regression analysis (Draper \& Smith 1980) and the fitting of compartmental models to tracer kinetic data (Berman et al. 1962, Smith 1974). The crucial difference is in the low ratio of observations to unknowns in the inverse problem, leading to indeterminacy in the solution.

The exact structure of the model depends on the information available and on whether food web fluxes are treated as linear or non-linear. The inverse formalism can handle any type of model (Parker 1977, Tarantola \& Valette 1982, Wunsch \& Minster 1982, Jackson 1985). We assume here that the biomass structure (in terms of one or several biogenic elements) and the boundary conditions for the food web can be specified from the observational data. For an open ocean food web, for example, the boundary conditions would be primary production and sedimentation. Independent estimates of other fluxes can also be included among the observations. Therefore, the observations that the inverse solution attempts to reproduce include the mass balances for each element considered and each compartment (assumed zero for a steady state system), the boundary flows, and additional food web flux estimates if possible, all constrained by the observed biomass structure of the food web. We also treat the flow parameters as constants, i.e. the model is linear. This restricts the domain of the inverse estimates of the fluxes to time and space scales over which non-linear variation of the rate constants can be neglected (Platt \& Harrison 1985, Vézina \& Platt 1987).

A requirement for conservation of mass alone does not guarantee a realistic flow network; the network should also satisfy known constraints on the rate and efficiency of biological processes. We must ensure, for example, that respiration is sufficient to meet the basic metabolic requirements of the biota or that the ingestion rate of consumers is not unrealistically high. In other words, we must make use of prior knowledge, when it is available, to set bounds on the parameters. The parameters can be constrained through setting limits on relationships among flows, for example, pro- 
duction efficiency or the ratio of oxygen consumption to ammonium production. Determining the bounds in this way is a subjective process. However, investigators are more likely to agree on such general criteria than on specific values for the rate and efficiency of biological processes. It is possible, then, to develop a standard set of constraints that can be applied to any food web.

\section{The inverse solution}

The solution process relies on the principle of parsimony: it generates the simplest flow network that satisfies both the mass conservation and biological constraints. It is the network where the parameters (rate constants) are the least different and where the sum total of parameter values is lowest. We do not wish to imply that food webs are organized on the principle of maximum simplicity. Our only aim is to produce a baseline flow network that can be compared within and across food webs. At this time, the operational requirement that the flow structure be as simple as possible seems no worse than any other, and certainly better than none.

We mentioned earlier that the inverse method is analogous to more traditional curve-fitting techniques in using observational data to solve for the parameters of a model. The analogy goes further in that the inverse solution, as the solution of a regression problem for example, is not expected to be perfect due to both errors in the data and inadequacies of the model. In other words, the solution will leave residuals when compared to the observed or assumed dynamics of the food web (i.e. mass balances, boundary flows, and other measured fluxes if applicable). These residuals can be useful in assessing a particular solution or comparing alternative solutions for the same data set.

Given the errors associated with the inverse solution, we may expect certain differences in the contribution of various observations toward the solution. To properly evaluate the inverse solution, it is important to know how much weight each observation carries in the resolution of the parameter estimates. As part of the solution process, resolution indices can be computed for each observation. These resolutions vary from 0 to 1. Observations with a zero resolution are redundant and could be dropped without changing the solution. Similarly, the solutions will be less sensitive to observations with low or mid-range resolution than to those with resolutions near 1 . Also, the observations with low resolution will leave disproportionately large residuals that will tend to skew the distribution of errors away from normality. These resolutions are indicators of the information content of the various dynamic observations that are used to derive the solution.
Analogous resolution indices can be computed for the components of the solution. In this case, the resolutions indicate the degree to which the parameters are constrained by the mass balance observations alone. Parameters with high resolutions (approx. 1) will change little after application of the biological constraints. The lower the resolution the stronger the effect of the additional constraints on the parameter. The parameter resolutions point to the fluxes whose inverse estimates are most sensitive to the a priori information. Poorly resolved fluxes that carry no, or only vague, prior expectations are clearly the weakest links in the solution for the flow network.

On the surface, resolutions appear useful in the design of observational programs since they rank the usefulness of observations and a priori information (Wunsch 1978). We caution against this interpretation, however, because resolutions are roughly proportional to the numerical magnitude of the observations that characterize the part of the model they represent (Wunsch \& Minster 1982). In the case of parameter resolutions, for example, this is equivalent to saying that fluxes that involve compartments with large standing stocks are less dependent on a priori information than fluxes that involve compartments with small standing stocks. Different resolutions would arise from imposing different weights on the data. From the point of view of inverse methods, all information is equally useful. We introduce the resolutions only as diagnostics of numerical problems that must be considered in interpreting the solution.

The procedures to set up the inverse problem and compute the solution are presented in the Appendix. Readers interested in more details are referred to the rich literature on the subject (Lanczos 1961, Jackson 1972, Wiggins 1972, Wunsch 1978, Wunsch \& Minster 1982, Bolin et al. 1983, Enting 1985).

\section{Final remarks}

Before we proceed with examples of the application of inverse methods to food web data, we should establish that the method generates a possible solution, not necessarily the correct solution. The non-uniqueness of the solution is a necessary consequence of the lack of information on food web dynamics in the ocean. With inverse methods, however, we can easily explore a number of solutions compatible with the data. We can systematically manipulate the mass balance and flow information and study the effects of these manipulations on the flow networks. Another possibility that we explore in a folow-up paper is to generate extreme flow networks using linear programming techniques. Here, we limit ourselves to the simplest solutions obtained 
under alternative closure conditions on the regeneration of nitrogen in the food web. First, we need to introduce a general framework for the application of the inverse machinery.

\section{GENERAL FRAMEWORK OF APPLICATION}

\section{Generic model of the oceanic food web}

To make full use of the capabilities of the inverse methodology, we designed a compartmental model that is potentially applicable to any food web system (Fig. 1). The generic model contains all possible flows connecting the biotic and abiotic compartments. The inverse solution will remove (zero) any flow that is not required to conserve mass and satisfy basic biological constraints. Five biotic compartments are identified: autotrophs, bacteria, protozoans (microflagellates and ciliates), microzooplankton and mesozooplankton. Operationally, the microzooplankton are the metazoans that can be caught in a water bottle $(<200 \mu \mathrm{m}$ in linear dimensions). Mesozooplankton are the metazoans $>200 \mu \mathrm{m}$ captured by plankton nets. The model includes compartments for the particulate detrital material and the dissolved organic matter. Estimates of $\mathrm{C}$ and $\mathrm{N}$ content are assumed available for all the compartments. In addition, the model includes com-

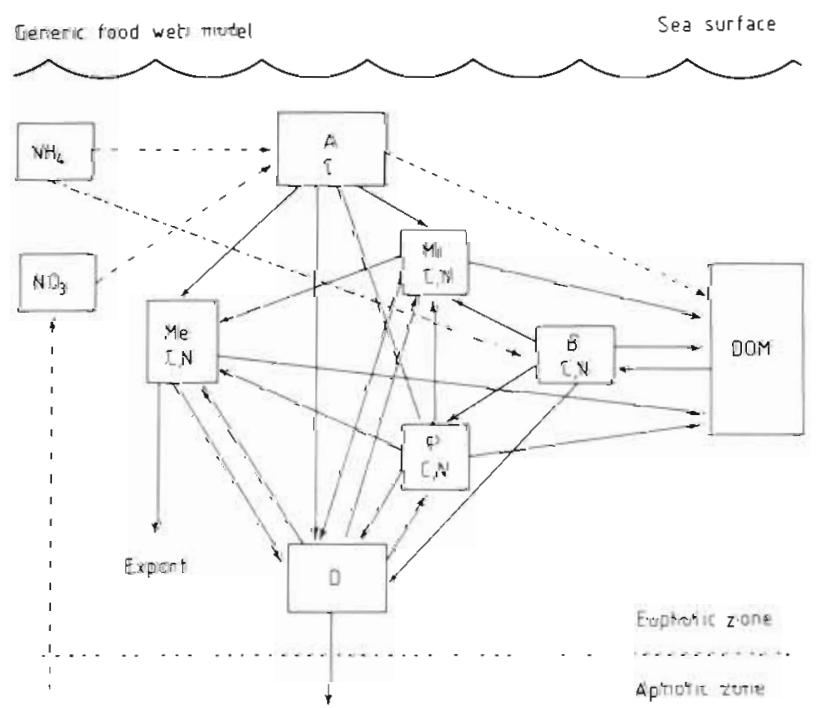

Fig. 1. Generic model of planktonic food webs in stratified waters. The compartments are: autotrophs (A), bacteria (B). protozoans (P), microzooplankton (Mi), mesozooplankton (Me), detritus (D), dissolved organic matter (DOM), nitrate $\left(\mathrm{NO}_{3}\right)$ and ammonium $\left(\mathrm{NH}_{4}\right)$. The letters $\mathrm{C}$ and $\mathrm{N}$ inside the boxes for the living compartments designate the flows that regenerate inorganic forms of those elements, i.e. respiration. $(\longrightarrow)$ Inter-compartmental flows of $\mathrm{C}$ and $\mathrm{N}_{i}(-\cdots)$ flows of $C$ only; $(-\rightarrow) N$ flows partments for nitrate, replenished from outside sources, and ammonium, a product of heterotrophic metabolism that is regenerated locally (Dugdale \& Goering 1967).

We assume that in the open ocean, the pelagic ecosystem is in quasi-steady state (Eppley \& Peterson 1979). The food web resides in a homogeneous mixed layer overlying nitrate-rich deep water. Horizontal mixing and advection are neglected. The only external exchanges are vertical; particulate organic matter sinks to the deep water and its nitrogen equivalent is replaced by upward diffusion of nitrate. The food web is driven solely by primary production; allochtonous inputs of organic matter are assumed negligible.

The network of potential flows includes respiration, excretion of dissolved organic material, and particulate losses to detritus by all living compartments, and 12 predator-prey flows. The feeding fluxes are initially constrained only by the size of the food particles: the protozoans, microzooplankton and mesozooplankton are taken to feed indiscriminantly on any compartment that contains particles of a size range accessible to them (Isaacs 1973). Hence, the protozoans can feed on the autotrophs, bacteria and detritus, but not on the micro- or mesozooplankton. The mesozooplankton, on the other hand, have access to all the particulate compartments, except bacteria (King et al. 1980, Boak \& Goulder 1983, Roman 1984). Mesozooplankton production is treated as a net export from the food web.

An important consideration is that organisms do not necessarily process materials such as $\mathrm{C}$ and $\mathrm{N}$ at the same rate (Corner \& Davies 1971, Lancelot \& Billen

Table 1. Key to the state variables of the generic food web model

\begin{tabular}{|rlr|}
\hline No. & Compartment or flux & Element \\
\hline 1 & Particulate organic matter & $\mathrm{C}$ \\
2 & Autotrophs & $\mathrm{C}$ \\
3 & Bacteria & $\mathrm{C}$ \\
4 & Protozoans & $\mathrm{C}$ \\
5 & Microzooplankton & $\mathrm{C}$ \\
6 & Mesozooplankton & $\mathrm{C}$ \\
7 & Detritus & $\mathrm{C}$ \\
8 & Dissolved organic matter & $\mathrm{C}$ \\
9 & Autotrophs & $\mathrm{N}$ \\
10 & Bacteria & $\mathrm{N}$ \\
11 & Protozoans & $\mathrm{N}$ \\
12 & Microzooplankton & $\mathrm{N}$ \\
13 & Mesozooplankton & $\mathrm{N}$ \\
14 & Detritus & $\mathrm{N}$ \\
15 & Dissolved organic matter & $\mathrm{N}$ \\
16 & Ammonium & $\mathrm{N}$ \\
17 & Net primary production & $\mathrm{C}$ \\
18 & Net primary production & $\mathrm{N}$ \\
19 & Gross primary production & $\mathrm{C}$ \\
20 & Sedimentation & $\mathrm{C}$ \\
\hline
\end{tabular}


1985). Therefore, rates of respiration, excretion and egestion, in fact any process involved in the breakdown and metabolization of biomass, are likely to necessitate separate parameters for $\mathrm{C}$ and $\mathrm{N}$. On the other hand, fluxes of whole particles (ingestion, sinking) can be described by a single parameter for both materials. We assume 'respiration' and excretion of $\mathrm{N}$ by autotrophs to be negligible, in accordance with current conceptions of the physiology of nutrientlimited microalgae (Fogg 1983).

In computing the inverse solution, we assume that, at a minimum, estimates of the $\mathrm{C}$ and $\mathrm{N}$ content of the various compartments and of the rates of primary production and sedimentation are available. The state variables and parameters of the generic model are listed in Tables 1 and 2. Note that the PON and $\mathrm{NO}_{3}$

Table 2. Key to the flows in the generic food web model

\begin{tabular}{|c|c|c|c|c|}
\hline No. & Description & Element & Type: & Notes \\
\hline 1 & Gross primary production & $\mathrm{C}$ & 2 & \\
\hline 2 & Autotrophic nitrate uptake & $\mathrm{N}$ & 2 & \\
\hline 3 & Autotrophic ammonium uptake & $\mathrm{N}$ & 2 & \\
\hline 4 & DOM uptake by bacteria & $\mathrm{C}, \mathrm{N}$ & 1 & \\
\hline 5 & Bacterial ammonium uptake & $\mathrm{N}$ & 2 & \\
\hline 6 & Autotrophic respiration & $\mathrm{C}$ & 1 & \\
\hline 7 & Bacterial respiration & C & 1 & \\
\hline 8 & Protozoan respiration & C & 1 & \\
\hline 9 & Microzoop. respiration & $\mathrm{C}$ & 1 & \\
\hline 10 & Mesozoop respiration & $\mathrm{C}$ & 1 & \\
\hline 11 & Bacterial regeneration & $N$ & 1 & Inorganic excretion \\
\hline 12 & Protozoan regeneration & $\mathrm{N}$ & 1 & Inorganic excretion \\
\hline 13 & Microzoop. regeneration & $\mathrm{N}$ & 1 & Inorganic excretion \\
\hline 14 & Mesozoop. regeneration & $\mathrm{N}$ & 1 & Inorganic excretion \\
\hline 15 & Autotrophic excretion & $\mathrm{C}$ & 1 & \\
\hline 16 & Bacterial excretion & $\mathrm{C}$ & 1 & \\
\hline 17 & Protozoan excretion & $\mathrm{C}$ & 1 & \\
\hline 18 & Microzoop. excretion & $\mathrm{C}$ & 1 & \\
\hline 19 & Mesozoop excretion & $\mathrm{C}$ & 1 & \\
\hline 20 & Bacterial excretion & $N$ & 1 & Organic excretion \\
\hline 21 & Protozoan excretion & $\mathrm{N}$ & 1 & Organic excretion \\
\hline 22 & Microzoop. excretion & $\mathrm{N}$ & 1 & Organic excretion \\
\hline 23 & Mesozoop. excretion & $\mathrm{N}$ & 1 & Organic excretion \\
\hline 24 & Dissolution of detritus to DOM & $\mathrm{C}, \mathrm{N}$ & 1 & \\
\hline 25 & Auto. detritus production & C, $\mathrm{N}$ & 1 & Mortality \\
\hline 26 & Bact. detritus production & C, $\mathrm{N}$ & 1 & Mortality, particle aggregation \\
\hline 27 & Protozoan egestion & C & 1 & \\
\hline 28 & Microzoop. egestion & $\mathrm{C}$ & 1 & \\
\hline 29 & Mesozoop. egestion & $\mathrm{C}$ & 1 & \\
\hline 30 & Protozoan egestion & $\mathrm{N}$ & 1 & \\
\hline 31 & Microzoop. egestion & $\mathrm{N}$ & 1 & \\
\hline 32 & Mesozoop. egestion & $\mathrm{N}$ & 1 & \\
\hline 33 & Grazing of auto. by protozoans & $\mathrm{C}, \mathrm{N}$ & 3 & \\
\hline 34 & Grazing of auto. by microzoop. & $\mathrm{C}, \mathrm{N}$ & 3 & \\
\hline 35 & Grazing of auto. by mesozoop. & $\mathrm{C}, \mathrm{N}$ & 3 & \\
\hline 36 & Grazing of bact. by protozoans & $\mathrm{C}, \mathrm{N}$ & 3 & \\
\hline 37 & Grazing of bact. by microzoop. & $\mathrm{C}, \mathrm{N}$ & 3 & \\
\hline 38 & Grazing of detr. by protozoans & $\mathrm{C}, \mathrm{N}$ & 3 & \\
\hline 39 & Grazing of detr. by microzoop. & $\mathrm{C}, \mathrm{N}$ & 3 & \\
\hline 40 & Grazing of detr by mesozoop. & $\mathrm{C}, \mathrm{N}$ & 3 & \\
\hline 41 & Grazing of prot. by microzoop. & C. $N$ & 3 & \\
\hline 42 & Grazing of microz. by mesozoop. & $C, N$ & 3 & \\
\hline 43 & Grazing of auto. by mesoz. & $\mathrm{C}, \mathrm{N}$ & 3 & \\
\hline 44 & Export of mesozoop. prodn. & $\mathrm{C}, \mathrm{N}$ & 3 & \\
\hline 45 & Sedimentation & $\mathrm{C}, \mathrm{N}$ & 4 & \\
\hline
\end{tabular}


components are non-negative $(\geq 0)$. We also add other constraints to our generic set based on a review of the ecophysiological literature (Table 3).

A fundamental constraint is that living organisms must respire a minimal fraction of the energy they capture for maintenance needs. For autotrophs, dark respiration can be expressed as a fraction of the gross primary production (Table 3). For heterotrophs, we used the method of Platt et al. (1984) to arrive at a plausible estimate of the aggregate minimal energy demand of the compartments. Briefly, respiration is predicted from size-dependent functions and integrated over a size range by assuming a simple monotonic size distribution of biomass. We set size ranges for each compartment (Sieburth et al. 1978) and assumed, to be conservative, that biomass was uniformly distributed over logarithmic size intervals (Sheldon et al. 1972, Rodriguez \& Mullin 1986). Keeping the size range and the size distribution constant, the biomassspecific respiration $\left[\mathrm{T}^{-1}\right]$ of each compartment becomes a constant multiplied by a temperature correction factor (Table 3). In the case of bacteria, the fraction of the measured biomass that is active is highly uncertain (Van Es \& Meyer-Reil 1982). Therefore, we assumed, again to be conservative, that only $30 \%$ of the bacterial biomass was active in computing minimum bacterial respiration. We used the same size-dependent integration technique to compute ceilings on the biomassspecific ingestion rates of protozoans and metazoans (Table 3)

We also know that there are limits to the efficiency of heterotrophic transformations. In the first place, some fraction of the material ingested by phagotrophs is always lost in particulate egesta. Also, the assimilated material is subjected to respiration and excretion losses before it is turned into biomass. Theoretically, the $\mathrm{C}$ growth efficiency can range from 0 to $80 \%$ (Calow 1977). The published experimental data, however, suggests that these extremes are rarely reached. Therefore, we used the literature to define somewhat narrower bounds (Table 3 ).

All planktonic organisms excrete organic metabolites that enter the pool of dissolved organic matter. There has been considerable interest recently in the excretion of DOC by autotrophs (Fogg 1983). The literature suggests that from anywhere between 1 to $>100 \%$ of gross primary production is in soluble form. We discarded infrequent extreme results to arrive at a smaller range of possibilities (Table 3). There is much less information on excretion by heterotrophs. The existing data suggest that DOC losses by protozoans and metazoans can be as high or higher than respiration and do not fall below $20 \%$ of respiration. Therefore, we set limits to excretion by grazers in relation to respiration (Table 3 ). No constraints (other than non-negativity) were put on bacterial DOC excretion as we did not find enough information on it. We also assumed an upper limit to the supply of dissolved organic matter from degradation of dead particulate matter (Table 3).

There are also limits to the variations in the $C: N$ ratios of physiological fluxes. The considerable information on the $\mathrm{C}: \mathrm{N}$ composition of fecal pellets and on the ratios of $\mathrm{O}_{2}$ consumption to ammonium regeneration of zooplankton suggests some broad ranges for the $\mathrm{C}: \mathrm{N}$ ratios of egestion and respiration fluxes for microand mesozooplankton (Table 3). In the virtual absence of similar information, the same ranges of ratios are applied for the egestion and respiration of protozoans and for bacterial respiration. The $\mathrm{C}: \mathrm{N}$ ratio of DOM excretion is left unconstrained due to the lack of pertinent data.

Similarly, we have no constraints other than nonnegativity on the production of detrital material by autotrophs and bacteria, and on the predation fluxes. One could put selectivity constraints on the ingestion of particulate material, but we chose not to do this because of the paucity of in situ data on feeding preferences by planktonic organisms and the responsiveness of feeding behaviour to food availability which makes generalizations difficult (Poulet 1983). We present this as our minimum set of constraints for the inversion of food web data.

\section{APPLICATIONS}

We now turn to the application of the methodology outlined above to the data on the structure and productivity of 2 food webs near the English coast. These data sets are among the most complete assessments of the biomass of all the major groups of planktonic organisms, including microheterotrophs, available so far. The observations were gathered in stratified waters in late summer, at a time when planktonic systems could be expected to reach a quasi-steady state. Both sets of observations are snapshots of their respective environments. On one hand, they fit our requirement that the time and space scales of the observations are small enough to exclude strong nonlinearities in the food web dynamics. On the other hand, the scale of observation may be too small: the numbers may be biased by local patchiness (Platt \& Conover 1971, Platt \& Denman 1980) and transient spatio-temporal separation of different food web components (Mullin \& Brooks 1976, Cox et al. 1983). Also, we assume in these analyses that the food web is in steady state, but the temporal changes in the structure of the food web are not documented in either data set. These data are not offered as the best currently available or as the best possible for the inversion methodol- 
ogy. They are used merely to illustrate the procedure and its scope; the flow networks we derive should be regarded as tentative.

\section{Food web fluxes in the western approaches to the English Channel}

Our first application is to the data of Holligan et al. $(1984 a$, b) that describes the food web of Stn E5 $\left(49^{\circ} 05^{\prime} \mathrm{N}, 6^{\circ} 37^{\prime} \mathrm{W}\right)$, located in stratified, relatively chlorophyll-poor waters west of the Ushant tidal front in the English Channel. Table 4 gives a summary of the

Table 4. Food web data for Stn E5, English Channel. Units of estimates are $\mathrm{mg} \mathrm{m}^{-2}$ for standing stocks and $\mathrm{mg} \mathrm{m}^{-2} \mathrm{~d}^{-1}$ for fluxes. Adapted from Holligan et al. $(1984 a$, b)

\begin{tabular}{|lc|}
\hline Variable & Estimate \\
\hline Physical environment & \\
Temperature $\left({ }^{\circ} \mathrm{C}\right)$ & 15 \\
$\mathrm{NO}_{3}-\mathrm{N}$ concentration & 40 \\
$\mathrm{NO}_{3}-\mathrm{N}$ gradient $\left(\mathrm{mg} \mathrm{m}^{-4}\right)$ & 0.08 \\
Standing stocks & \\
Particulate organic C & 7356 \\
Particulate organic $\mathrm{N}$ & 850 \\
Autotroph C & 420 \\
Bacterial C & 142 \\
Protozoan C & 118 \\
Microzooplankton C & 286 \\
Microzooplankton N & 65 \\
Mesozooplankton C & 682 \\
Mesozooplankton N & 144 \\
DoC & 34656 \\
Fluxes & \\
Gross primary production & 720 \\
Net primary production & 480 \\
\hline
\end{tabular}

data for the surface waters ( 0 to $24 \mathrm{~m}$ ) of Stn E5. The data include estimates of particulate organic carbon (POC) and of its partitioning among the major taxonomic categories of plankton. Particulate organic nitrogen (PON) was measured as well as the organic $\mathrm{N}$ content of micro- and mesozooplankton. We calculated the average temperature, the $\mathrm{NO}_{3}$ concentration and the $\mathrm{NO}_{3}$ gradient from digitizations of the vertical profiles shown in Holligan et al. (1984a). For primary productivity estimates, we used the median of the values recorded over a period of several days in the area (Holligan et al. 1984b, Newell \& Linley 1984). We took $\mathrm{O}_{2}$ exchanges to measure gross production and ${ }^{14} \mathrm{C}$ uptake to measure net production (Williams et al. 1983. Smith et al. 1984). Sedimentation was estimated from the empirical function of Betzer et al. (1984) which indicates that the $C$ flux across the base of the euphotic zone amounts to nearly $40 \%$ of the $\mathrm{C}$ produced. This agrees with the estimate of the new production in that system based on analyses of the $\mathrm{NO}_{3}$ vertical profiles (Holligan et al. 1984b).

The biomass data did not include assessments of detrital matter, DON, and of $\mathrm{N}$ in phytoplankton, bacteria, and protozoans. We converted the $\mathrm{C}$ contents of the microheterotrophs to $\mathrm{N}$ content using an average $\mathrm{C}: \mathrm{N}$ ratio $(\mathrm{wt} / \mathrm{wt}$ ) of 4.25 (Fenchel \& Harrison 1976 , Heinbokel 1978, Finlay \& Uhlig 1981, Lancelot \& Billen 1985). The C:N ratio of DOM is highly variable (Williams 1975, Jackson \& Williams 1985). The data of Jackson \& Williams (1985) show that DOM is almost invariably $\mathrm{N}$-depleted relative to the particulate

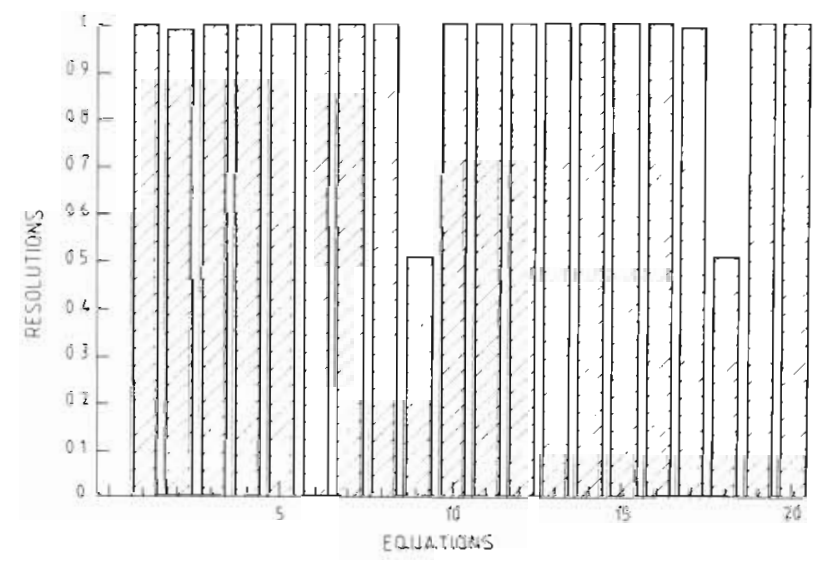

Fig. 2. Resolutions of the mass balance observations for the data of Stn E5. Resolutions can range from 0 to 1 and measure the contribution of each observation to the inverse solution. A resolution near 0 indicates that the observation carries very little weight in the solution. The numbers on the abscissa refer to the observations (state variables) listed in Table 1

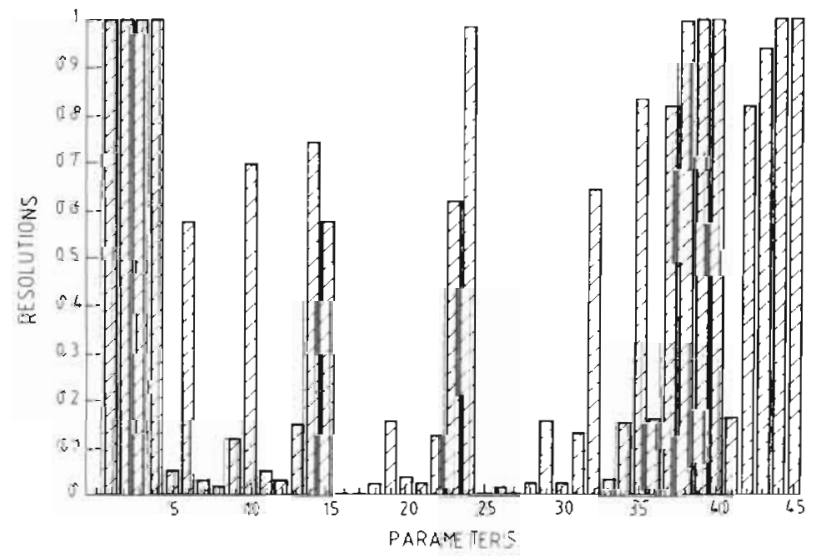

Fig. 3. Parameter resolutions for the data of Stn E5. Resolutions range from 0 to 1 and indicate the contribution of the mass balance observations as a whole to the final estimate of each food web flux. Estimates with resolutions near 1 are largely fixed by the mass balance constraints alone; those with resolutions near 0 are mostly dependent on the additional biological constraints. Numbers on the abscissa refer to the parameters listed in Table 2 
material. We assumed a $C: N$ of 12 (wt/wt) to convert from DOC to DON concentration. The $C: N$ ratio of phytoplankton was set at 8.0 (Holligan et al. 1984b). Once these conversions are made, the $\mathrm{C}$ and $\mathrm{N}$ in the detritus can be calculated by difference between the content of the particulate organic matter and that of the living compartments. We recognize that the phytoplankton $\mathrm{C}: \mathrm{N}$ can vary substantially depending on their nutritional state (Goldman et al. 1979, Lancelot \& Billen 1985). Our only defense is that the aspects of the inverse solution discussed below are insensitive to different assumed phytoplankton $\mathrm{C}: \mathrm{N}$ ratios.

There is little variation in the resolving power of the 20 state variables in the generic food web model (Fig. 2). Almost all the resolution indices are 1. The only exceptions are the resolutions for the mass balance conditions on phytoplankton $\mathrm{N}$ biomass and $\mathrm{N}$ assimi-

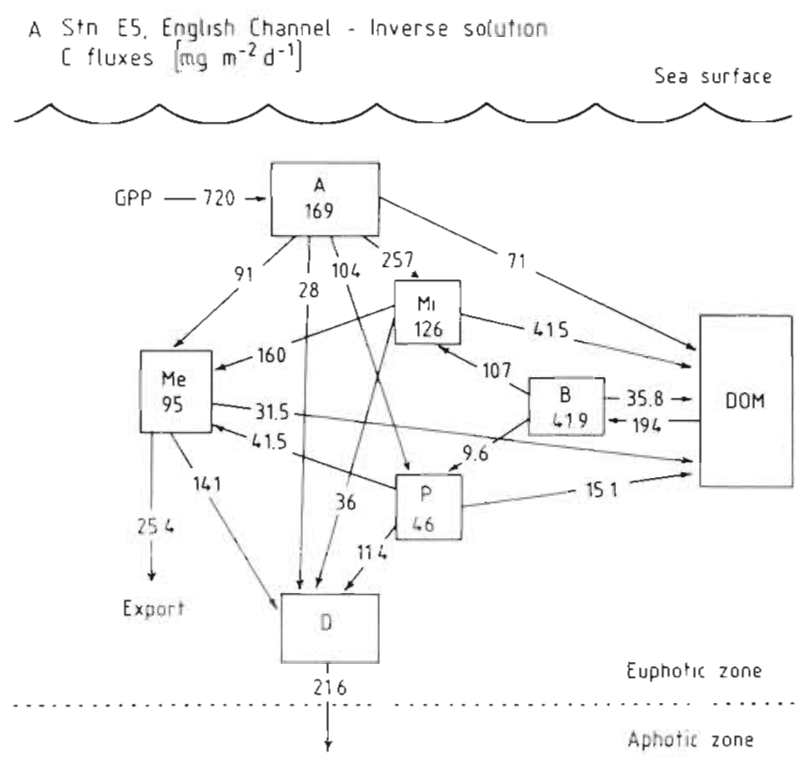

Fig. 4. Inverse solution for the food web fluxes at Stn E5. Panels portray: (A) C flows; (B) N flows; and (C) C:N ratios (wt/wt) of flows. Flows are given in $\mathrm{mg} \mathrm{m}^{-2} \mathrm{~d}^{-1}$ Numbers inside boxes refer to respiration flows (see Fig. 1 for definitions of the compartments) lation which are $\sim 0.5$ each. These 2 conditions are not independent. Therefore, there are 19 independent mass balance conditions on the inverse solutions, not 20 as initially posed.

The parameter resolutions are as expected: they are highest for the measured or specified fluxes (primary production, sedimentation) and for those that involve large standing stocks (mesozooplankton, detritus, DOM) (Fig. 3). The fluxes through the bacteria, protozoans and microzooplankton compartments are the most sensitive to the a priori information. The inverse estimates for those fluxes are likely to vary substantially depending on the conditions imposed in addition to the mass balance constraints (e.g. biological constraints) or the criterion used to derive the solution (e.g. maximum simplicity). On the other hand, the estimates with high resolutions will tend to be similar among
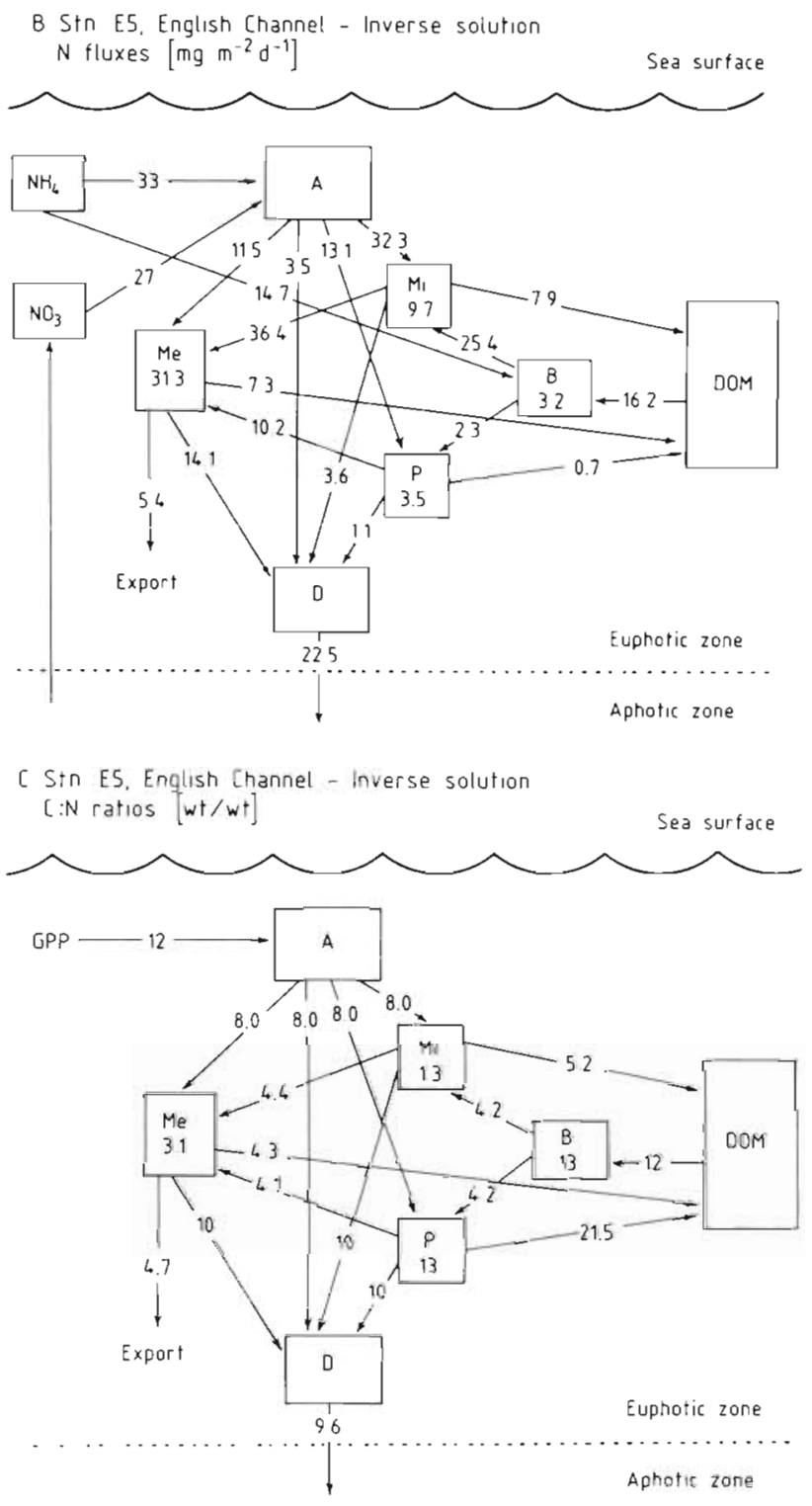

[ Stn ES, Enqlish Channel - inverse solution 
alternative solutions. This will hold true as long as the biomass structure of the food web is held constant: significant changes in the partitioning of $\mathrm{C}$ and $\mathrm{N}$ among the compartments will alter the solution and its resolution structure.

The inverse solution for the food web fluxes is shown in Fig. 4. The striking feature is that the microbial grazers appear as the major link in the transport of $C$ to the mesozooplankton (Fig. 4A): close to $70 \%$ of the mesozooplankton demand is supplied by the microzooplankton and the protozoans. The bacteria themselves are not a major link: they supply only $24 \%$ of the micrograzer demand and, indirectly, $17 \%$ of the C flux through the mesozooplankton. Virtually all of the particulate primary production finds its way directly or indirectly to the mesozooplankton, where a large proportion is unassimilated and serves to feed the downward C flux. Simple mechanistic arguments suggest that, in some systems at least, most of the vertical flux is mediated by zooplankton fecal pellets (Turner \& Ferrante 1979, Fowler et al. 1987). The inverse solution for Stn E5, generated from a mass balance approach to food web dynamics, supports this description of the source of the downward particulate flux.

On the other hand, the inverse solution paints an anomalous picture of $\mathrm{N}$ cycling in the food web of Stn E5. The bulk of the empirical evidence suggests that most, if not all, of the regenerated $N$ is supplied by the microplankton in marine food webs (Harrison 1980, Glibert 1982). In the inverse solution, the mesozooplankton supply $66 \%$ of the regenerated $N$ (Fig. 4B) even though their share of the respiration is only $20 \%$ As noted above, most of the primary production is routed to the mesozooplankton via the N-rich micrograzers. As a result, the mesozooplankton can afford a low $\mathrm{N}$ retention efficiency, as reflected in their high ratio of inorganic $N$ excretion to $C$ respiration (Fig. $4 \mathrm{C}$ ) This is the most parsimonious avenue that balances the $\mathrm{N}$ budget and maintains the food web structure observed at Stn E5.

As a preliminary assessment of the robustness of this unconventional result, we attempted an inverse solution with the additional constraint that microplankton regeneration balances the uptake of reduced $\mathrm{N}$ by phytoplankton and bacteria, i.e. there is a tight coupling between demand and supply by the microplankton (Glibert 1982). The residuals of the mass balance conditions for the solutions with and without coupling are shown in Fig. 5. The tight coupling solution resulted in consistently larger residuals and unacceptably large imbalances in certain compartments. The equations are incompatible; that is, there are no solutions that will balance the mass flows and maintain the structure of the food web under the tight coupling constraint. There are inverse solutions, based on criteria other than maximum parsimony, that allow a larger share of the regeneration by the microplankton (Vézina \& Platt unpubl.). However, it appears that, from a mass balance point of view, the mesozooplankton are an essential part of $N$ recycling in the euphotic zone of Stn E5 in August.

\section{Food web fluxes in the Celtic Sea}

Our second example is from the Celtic Sea, Stn CS2 $\left(50^{\circ} 30^{\prime} \mathrm{N}, 07^{\circ} 00^{\prime} \mathrm{W}\right)$. The published standing stock data (Table 5; Joint \& Pomroy 1983, Joint \& Williams 1985) are less comprehensive than at Stn E5. There is no information on DOC levels or on the organic $N$ content of the compartments. The DOC concentration was arbitrarily fixed at $1 \mathrm{mg} \mathrm{C}^{-1}$, a representative value for the ocean (Williams 1975). We assumed a
Fig. 5. Residuals of the mass balance conditions for alternative inverse solutions of the food web dynamics of Stn E5 (English Channel) in late August. For each condition (equation), open bar is the residual for the generic solution (Fig. 1); solid bar is the residual for the solution under the additional constraint that microplankton regeneration alone balances the uptake of reduced $\mathrm{N}$ by phytoplankton and bacteria. Numbers on abscissa refer to the state variables listed in Table 1

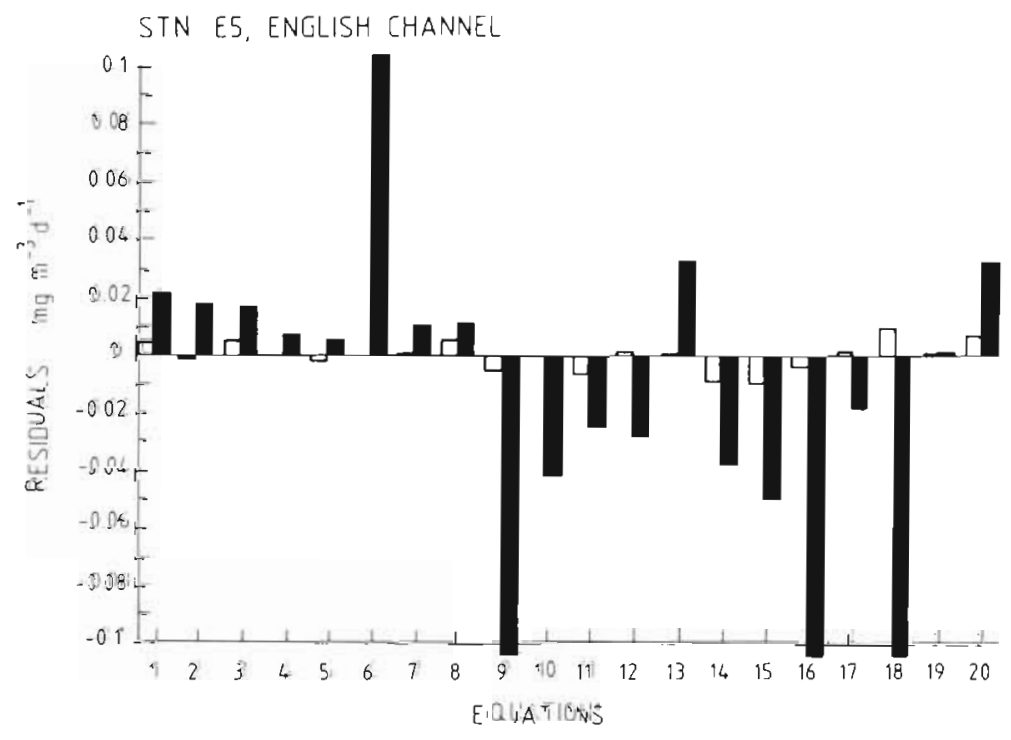


Table 5. Food web data for Stn CS2, Celtic Sea. Units as in Table 4. Adapted from Joint \& Pomroy (1983) and Joint \& Williams (1985)

\begin{tabular}{|lc|}
\hline Variable & Estimate \\
\hline Physical environment & \\
Temperature $\left({ }^{\circ} \mathrm{C}\right)$ & 16 \\
$\mathrm{NO}_{3}-\mathrm{N}$ gradient $\left(\mathrm{mg} \mathrm{m}^{-4}\right)$ & 0.06 \\
Standing stocks & \\
Particulate organic C & 625 \\
Autotroph C & 918 \\
Bacterial C & 50 \\
Protozoan C & 144 \\
Microzooplankton C & 166 \\
Mesozooplankton C & 1033 \\
Fluxes & \\
Net primary production & 585 \\
Soluble primary production & 72 \\
Bacterial production & 10 \\
\hline
\end{tabular}

$\mathrm{C}: \mathrm{N}$ conversion factor of 4.25 (wt/wt) for both the microheterotrophs (see above) and the zooplankton (Raymont et al. 1964, Beers 1966, Dagg 1976, Ross 1982, Hirche 1983, Small et al. 1983, Bottrell \& Robins 1984, Checkley \& Entzeroth 1985). The C:N ratios of POM and phytoplankton were set at 8.0 as for Stn E5. The productivity data includes particulate and soluble ${ }^{14} \mathrm{C}$ production and estimates of bacterial $\mathrm{C}$ production (Table 5; Joint \& Pomroy 1983). For primary production, we used the median of the values recorded over the late summer (July-August); the bacterial production rate is the average of measurements on 2 separate dates in late August. Gross primary production was calculated by assuming that respiration losses were identical to the excretion losses measured. Sedimentation was computed from the algorithm of Betzer et al. (1984) as before. The information on autotrophic DOC excretion and bacterial production was incorporated as additional mass balance constraints.

The inverse solution for Stn CS2 is shown in Fig. 6. In this solution, the constraint on bacterial production was ignored. In our first trials, we found that the estimate of bacterial production was incompatible with a balanced flow network. Joint \& Williams (1985) concluded, on the basis of the extremely low bacteria production rates reported by Joint \& Pomroy (1983), that the microbial loop did not contribute significantly to the production of higher trophic levels. The rates were inferred from thymidine incorporation data using very conservative conversion factor values, especially for bacterial carbon content. If more common conversion factors are used (H. Ducklow pers. comm.), the average measured rate (Table 5) is brought very close to that inferred from the inversion (100 vs $\left.126 \mathrm{mg} \mathrm{C} \mathrm{m} \mathrm{m}^{-2} \mathrm{~d}^{-1}\right)$. The inversion procedure was able to detect an inconsistency in the data set that can be supported by independent considerations.

The inverse solution for Stn CS2 is structurally almost identical to that of Stn E5, with differences only in the quantitative details. The mesozooplankton again are the dominant source of falling detrital material (Fig. 6A). As before, bacteria constitute a small indirect source of $\mathrm{C}$ for the mesozooplankton, supplying $12 \%$ of their demand. The major difference between the solutions for E5 and CS2 is that the mesozooplankton at CS2 obtain most of their C directly from the phytoplankton instead of indirectly through the micrograzers. In general, the mesozooplankton account for a larger share of the C fluxes at CS2 than at E5; they also hold a larger proportion of the biomass at CS2. In both stations, however, the general $\mathrm{C}$ flow pattern is the same: the primary production is routed, directly or indirectly, to the mesozooplankton where a significant unassimilated fraction is the dominant contribution to the downward flux.

According to the inverse solution, the mesozooplankton dominate $\mathrm{N}$ regeneration at $\mathrm{CS} 2$ (Fig. $6 \mathrm{~B}$ ) as they do at E5. The pattern in the $\mathrm{C}: \mathrm{N}$ ratios of respiration/ regeneration fluxes was the same as at E5, indicating that the microheterotrophs are more efficient at retaining $N$ than the mesozooplankton (Fig. 6C). Again, the tight coupling model, which assumes that microplankton supply balances the demand for reduced $N$, proved incompatible with the available data and the steady state assumption. Mesozooplankton regeneration is essential to compensate for $\mathrm{N}$ demand in thal sysiem.

\section{CONCLUSION}

This first application of the inverse formalism to food web data suggests a common pattern of material fluxes in the surface waters of coastal systems in late summer: the particulate primary production flows, directly or via the efficient micrograzer pathway, to the mesozooplankton that in turn fuel most of the downward particulate flux and $\mathrm{N}$ regeneration. Except for the $\mathrm{N}$ regeneration pattern, these inverse flow networks are in accord with current general concepts of material cycling in pelagic systems. This is to be expected. Inverse methods are powerful diagnostic tools that allow investigators to assimilate data within the framework of independently corroborated models. They are not meant to test models or hypotheses or reveal new phenomena. This is the province of planned experiments and theoretical analyses. In general, discrepancies between inverse solutions and empirical knowledge should not be interpreted in favor of the inverse solution.

Nevertheless, the application of inverse methods 

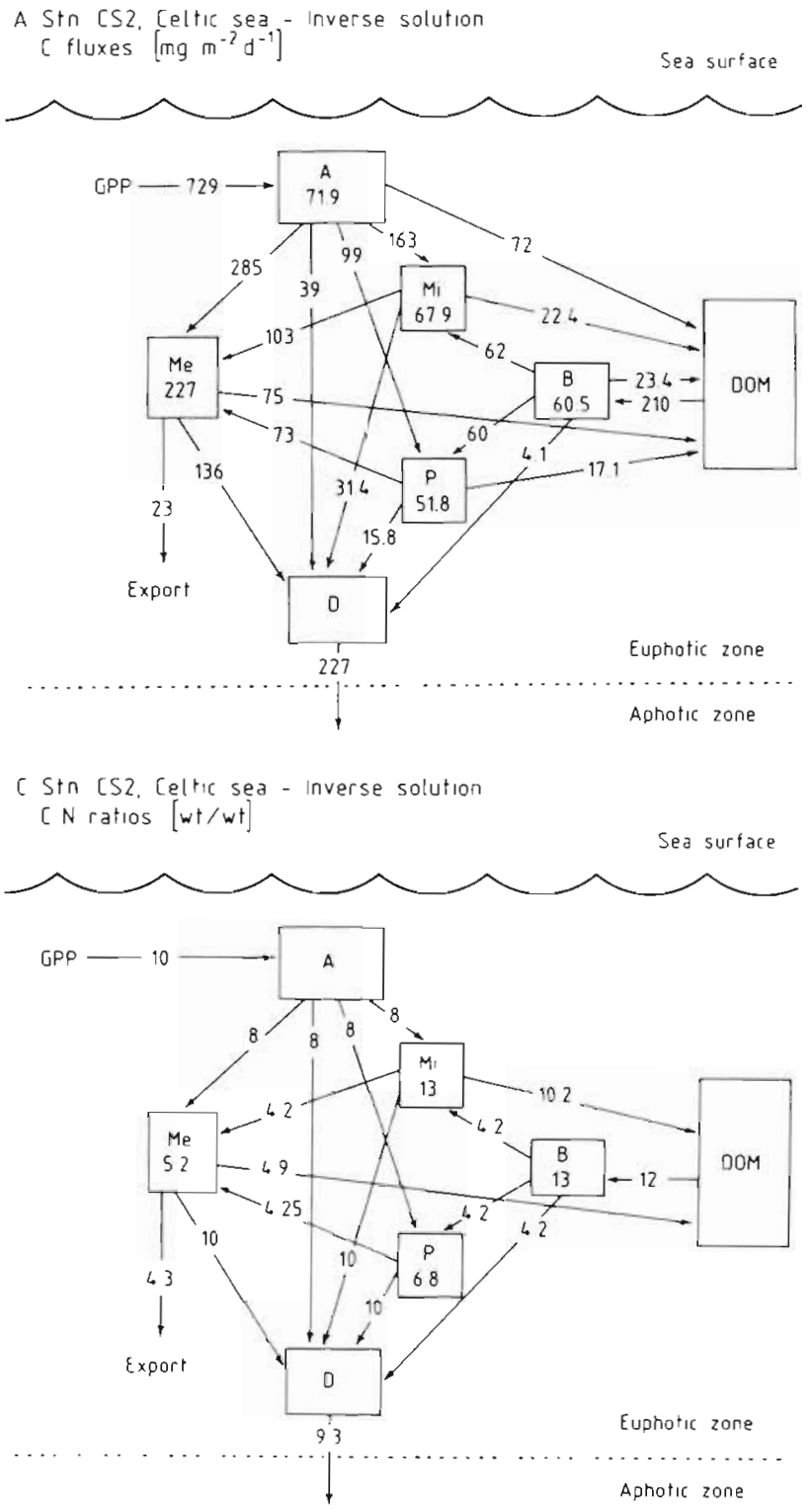

may sometimes expose that certain data or empirical generalizations conflict with an internally consistent interpretation of the data. We presented 2 examples of such a situation: (1) the bacterial production estimates for Stn CS2, and (2) the generalization that microplankton regeneration is tightly coupled to $\mathrm{N}$ demand. In the former case, there was independent support for treating the production estimate as erroneous. In the latter case, there may be a number of possible explanations, including problems with the data. For example, the inverse solution is sensitive to the standing stocks assigned to the various compartments and the biomass of the microbial components may have been grossly underestimated (Sherr et al. 1986). On the other hand, the inverse method may be diagnosing a situation where the generalization does not hold. Independent confirmation of this would be required.
$8 \sin$ [S2, [eltic sea - Inverse solution $N$ fluxes $\left[\mathrm{mg} \mathrm{m} \mathrm{m}^{-2} \mathrm{~d}^{-1}\right]$

Sea surface

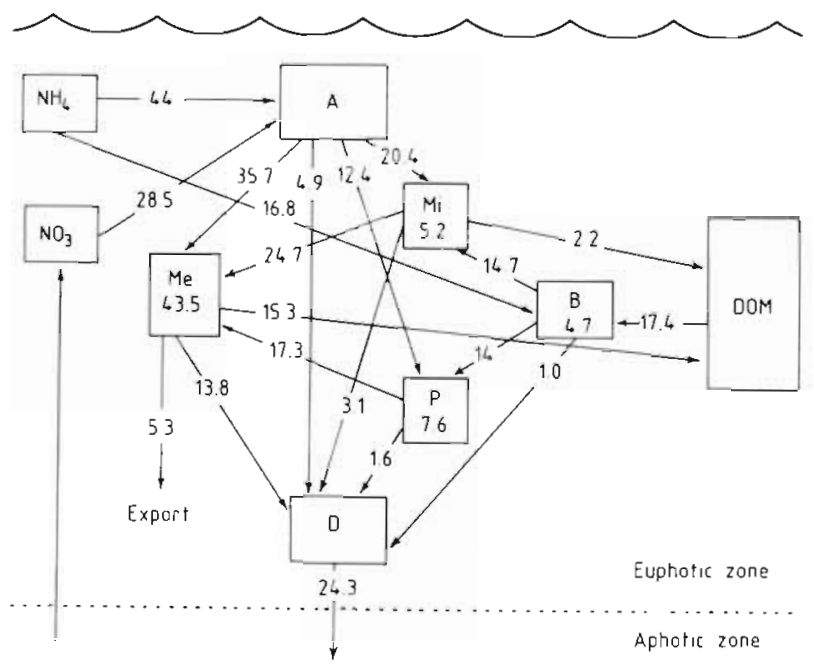

Fig. 6. Inverse solution for the food web fluxes at Stn CS2

A most important contribution of inverse methods is that they provide the foundation for an effective comparative analysis of food web dynamics in marine systems. It is important to realize that, in comparative analyses of marine food webs, we are dealing with differences among alternative models of the dynamics at one site as much as differences among sites. To our knowledge, the inverse method is the only method that provides a systematic way of comparing flow networks. We know that the inverse solutions for the different food webs being compared are the simplest solutions compatible with the site-specific data and generally applicable constraints. Other criteria than the principle of parsimony can be used to derive solutions (Vézina \& Platt unpubl.). The point is that we can classify alternative solutions as well as ecosystems. This is very important in view of the growing interest into holistic 
measures of ecosystem structure and function (Ulanowicz \& Platt 1985) that are computed from flow networks.

Naturally, we should work to reduce the indeterminacy of the solution, that is, increase the ratio of the number of independent observations $(\mathrm{k})$ to the number of unknowns (n). One way to achieve this would be to add more independent estimates of in situ fluxes. Unfortunately, such measurements are obtained mostly from incubation methodology that suffers from many well-known limitations in terms of accuracy (Ducklow et al. 1986) and sampling resolution (Jenkins \& Goldman 1985, Platt \& Harrison 1985). A more fruitful approach may be to incorporate observations of additional tracers, as long as they do not introduce new unknowns faster than they decrease the indeterminacy in the solution. For example, using only $\mathrm{C}$ for the inversion of Stn E5, $\mathrm{k}: \mathrm{n}$ is 0.27 ; adding $\mathrm{N}$ increased the ratio to 0.40 . The returns decrease rapidly when tracers that have basically the same history through the food web are introduced (for example, adding $P$ would increase the $\mathrm{k}: \mathrm{n}$ to 0.46 only). However, the inverse formalism can accomodate information on tracers of specific biological, chemical and physical processes; for example, $\mathrm{O}_{2}$ and $\mathrm{CO}_{2}$ for primary production and respiration (Shulenberger \& Reid 1981, Jenkins 1982, Brewer et al. 1986), chlorophyll and degradation products for herbivory (Wang \& Conover 1986), and isotopic Thorium for sedimentation (Coale \& Bruland 1987).

In many ways, inverse methods are the natural tool for the growing use of tracers to infer estimates of biological fluxes in marine systems. Simultaneous treatment of different tracer observations in a unified framework reduces the number of arbitrary boundary conditions that must be introduced to compute fluxes. Furthermore, inverse techniques deal effectively with the errors and redundancies in the information, ensure internally consistent interpretations, and facilitate the exploration of alternative networks consistent with the data. Awareness of the capabilities of inverse methods should promote a unified approach to the study of the physical, chemical and biological aspects of biogeochemical cycling in the ocean and encourage the design and implementation of interdisciplinary observational programs (Intergovernmental Oceanographic Commission 1984).

\section{APPENDIX}

Setting up the food web inverse problem. The food web compartmental model is translated into difference equations that are functions of state variables $\left(x_{i}\right)$ and rate parameters $\left(r_{j}\right)$ :

$$
\begin{aligned}
\mathrm{f}\left(x_{i}, r_{j}\right) & =\Delta x_{i} / \Delta t \\
i & =1, \ldots, \mathrm{m} \\
j & =1, \ldots, n
\end{aligned}
$$

In the linear case, the system of difference equations that describes the food web fluxes can be expressed in compact matrix notation:

$$
A r=b
$$

where $A=$ an $m \times n$ matrix that contains the state variables; $I=$ an $n \times 1$ vector of the unknown $r_{j}$ s; $b=$ an $m \times 1$ vector of the $\Delta x_{i} / \Delta t$ terms. Prior estimates of primary production and other flows can be used in the inversion in one of two ways. Measurements of individual fluxes can be lumped with the $\Delta x_{i} / \Delta t$ terms on the right-hand side of the affected mass balance equations and the corresponding $\Gamma_{j}$ terms dropped from the equations. Alternatively, additional equations that specify the value of the flow $(Q)$,

$$
\mathrm{f}\left(x_{i}, r_{j}\right)=Q
$$

can be appended to the mass balance equations. This is the only method available when measurements refer to a compounding of several flows. This method is also best for dealing with uncertainties in the observational data. Let $m$ refer to the number of equations in the expanded set. Then $b$ represents the flows and the standing stock changes that are fixed by observation or assumption, and will be termed here the dynamic vector. A represents the average state of the food web over the temporal and spatial scale of obscrvation and is designated here as the state matrix. Thus, Eq. (2) is a statement of the relationship between the state of the food web and its known or assumed dynamics and will be called the continuity equation.

In addition to the observational data, we need to specify a set of inequality constraints on the parameters that represents our prior knowledge of the food web processes. Most useful constraints can be described as linear inequalities of the form:

$$
\begin{aligned}
\sum g_{i j} r_{j} & \geq h_{i} \\
& i=1, \ldots, n_{c} \\
j & =1, \ldots, n
\end{aligned}
$$

where $g_{i j}=$ the coefficients of the inequality; $h_{i}=$ the lower bound condition that the inequality must meet. The inversion procedure can only solve for lowerbound inequalities; an upper-bound condition can be changed to a lower bound by multiplying the inequality through by -1 . Expressing the set of $n_{C}$ inequalities in matrix form, we have:

$$
G r \geq h
$$

where $G=$ the $n_{C} \times n$ matrix of coefficients; $h$ is the 
$n_{c} \times 1$ vector of inequality conditions. Eq. (5) is termed here the constraint equation.

The continuity and the constraint equations together define the conditions that the flow network for the food web system must meet. The procedure to compute the solution $r$ needed to recover the network flows follows.

Finding the simplest solution. The constrained inversion procedure works in 2 steps. First, the simplest solution to the continuity equation is found. The inequality constraints are then applied to this initial solution to yield a new solution that satisfies both the mass conservation and the additional biological constraints. The second solution is more complex than the first, but remains the simplest among the biologically realistic flow networks.

If $A$ is square $(m=n)$, the solution to the continuity equation is given by:

$$
A^{-1} b=r
$$

In the inverse problem, however, $m<n$ (fewer equations than unknowns), and $A^{-1}$ does not exist. We can solve for at most $m$ unknowns explicitly. In practice, redundancies and errors in the data reduce the effective number of equations available to solve for $r$. Therefore, the index $k(k \leq m)$ is used to designate the number of solvable unknowns

Nevertheless, we can find a particular solution to the inverse problem if we reparametrize the continuity equation to express the $n r_{j}^{\prime}$ s in terms of $k$ unknowns. To do this, the $n$-dimensional space spanned by the original parameters (the columns of $A$ or the parameter space) must be reduced to a $k$-dimensional space. This is exactly analogous to data reduction techniques, such as principal component analysis, where the information contained in multiple observations of a large number of variates (dimensions) is re-expressed into a much smaller number of transformed variables that are linear combinations of the original data. At the same time, since usually $k<m$, we also want to reduce the $m$ dimensions spanned by the mass balance equations (the rows of $A$ or the observation space) to $k$ dimensions. By factoring $A$ into $k$-dimensional subspaces of its observation and parameter spaces, we can solve explicitly for $k$ unknowns and, knowing the relationship between those unknowns and the original parameters, we can reconstruct a particular solution to the continuity equation.

This is achieved through the Singular Value Decomposition (SVD) of $A$ :

$$
A=U L V^{\mathrm{T}}
$$

where $U=$ an $m \times k$ matrix containing $k$ independent linear combinations of the rows of $A$ that span the observation space; $V=$ an $n \times k$ matrix of linear combinations of the columns of $A$ that span the para- meter space; $L=$ a diagonal $k \times k$ matrix of scaling factors $\left(l_{1}, i=1, \ldots, k\right)$. Technically, the SVD is the solution to a coupled eigenvalue problem (Lanczos 1961); thus the columns of $U$ and $V$ are commonly referred to as the observation and parameter eigenvectors of $A$ and the $l_{i}$ terms as the singular values. The singular values are ranked in decreasing order along the diagonal of $L$ and indicate the proportion of the total information contained in $A$ that is accounted for by the ith column of $U$ and $V$, in direct analogy to the eigenvalues in principal component analysis that denote the proportion of the total variance in the original data that is accounted for by the associated principal component.

With the SVD, the continuity equation can be rewritten as:

$$
U L V^{\mathrm{T}}{ }=b
$$

which can be solved immediately for $r$ :

$$
r=V L^{-1} U^{\mathrm{T}} b
$$

We can now see the formal role of the SVD as a reparametrization of the original model. Let

$$
c=L^{-1} U^{\mathrm{T}} b
$$

where $c$ is $a \mathrm{k} \times 1$ vector of unknowns that can be solved for explicitly as the weighted projection of the dynamic vector on the $k$-dimensional version of the observation space. Simplifying Eq. (9) using (10), we obtain:

$$
r:=V c
$$

This equation is a statement of the relationship between the $k$ solvable unknowns and the $n$ parameters that we wish to estimate.

That the particular solution $r$ is not unique can now be seen in a formal way. We could make $V$ square by adding $n-k$ column vectors that are mutually independent and independent of the original $k$ columns. This new $V$ would be an equivalent representation of the parameter space of $A$. Thus, appending arbitrary values to $c$ to increase its length to $n$ would result in a new solution that also satisfies the continuity equation. The $n-k$ column vectors needed to square $V$ fill the null space of $A$, the part of the $n$-dimensional parameter space that has no correspondence with the $k$-dimensional observation space. If we collect these additional vectors into a $n \times n-k$ matrix $V^{\prime}$, we can compute a new solution $\left(r_{n}\right)$ to the continuity equation as

$$
r_{n}=V_{C}+V^{\prime} d
$$

or,

$$
I_{n}=r+V^{\prime} d
$$

where $d$ is a $n-k \times 1$ vector of arbitrary constants. An 
infinity of solutions could be generated just by changing the components of $d$.

It is also clear that $r$ will be the simplest among all non-trivial solutions to the continuity equation. The simplicity of a solution, as we described it earlier (absolute values of the solution components and the differences among components as small as possible), is geometrically the distance between the point it defines in the $n$-dimensional parameter space and the origin (0) representing the trivial solution. Algebraically, this distance is measured as the norm of $r(\| r||)$, where:

$$
\|r\|=\Sigma r_{j}^{2}
$$

It is evident that the addition of null space terms ( $\left.V^{\prime} d\right)$ can only increase $\|r\|$, hence the complexity of the solution.

We now have a basis for the derivation of constrained solutions. Recall that the additional constraints are specified through the constraint equation,

$$
G I_{n 2} \geq h
$$

Since $r$ is fixed as the solution to the continuity equation, we wish to re-express the constraint equation in terms of the free parameters $d$. Substitutiong for $r_{n}$ in Eq. (5) we obtain,

$$
\begin{aligned}
& G\left(r+V^{\prime} d\right) \geq h \\
& G V^{\prime} d \geq h-G r
\end{aligned}
$$

Before we proceed, we need to construct $V^{\prime}$, that is to generate $n-k$ independent linear combinations that span the null space of $A$. Given that we have no information on the null space, we can fill it with columns of random numbers that are mutually independent and independent of the original $k$ columns. We present without proof (see next section) the method of $\mathrm{Fu}$ (1981) to achieve this. $V^{\prime}$ is constructed by orthogonalizing the following matrix $M$ :

$$
M=\left(I-V V^{\mathrm{T}}\right) P
$$

where $P=$ a $n \times(n-k)$ matrix of random numbers. The modified Gram-Schmidt method (Nash 1979) can be used for the orthogonalization. Let $G^{\prime}=G V^{\prime}$ and $h^{\prime}=$ $h-G r$. The result is a new set of linear inequality constraints on $d$ :

$$
G^{\prime} d \geq h^{\prime}
$$

Since we do not wish to introduce any unnecessary complexity into $r_{n}$, we want to compute the simplest possible $d$ that satisfies the inequalities, or:

$$
\begin{aligned}
& \text { Minimize } \quad\|d\| \\
& \text { subject to } \quad G^{\prime} d \geq h^{\prime}
\end{aligned}
$$

This is a quadratic programming problem that can be solved using a least distance algorithm (Lawson \&
Hanson 1974). The vector $d$ can now be substituted into Eq. (12) to recover the constrained solution $r_{n}$

Due to errors and redundancies in the data, the problem of estimating food web fluxes from observational data is really the least-squares problem of finding the solution $r_{n}$ that

$$
\begin{array}{cl}
\underset{\text { minimizes }}{\text { and }} & \left\|A r_{n}-b\right\| \\
& \left\|r_{n}\right\| \\
\text { subject to } & A r_{n}=b \\
\text { and } & G r_{n} \geq h
\end{array}
$$

We assume that the residual errors left by the leastsquares solution (e) are randomly and independently distributed with uniform variance $\left(\sigma^{2}\right)$, i.e. $e=I \sigma^{2}$ (unweighted least-squares). There are a number of ways one could proceed to find the most appropriate least-squares solution (Wunsch 1978). We chose the cut-off method (Wiggins 1972). This method exploits the fact that the magnitude of the residual error $\left(\left\|A r_{n}-c b\right\|\right)$ and the complexity of the solution $\left(\left\|r_{n}\right\|\right)$ depend on $k$, the number of dimensions used to represent the observation and parameter spaces of $A$ (Fig. A1). A disproportionate increase in the complexity of the solution for $k$ close to $m$ is diagnostic of noise and redundancy in the state matrix. On the other hand, rapid increases in the residual norm as $k$ is lowered indicate that information required to approximate a closed mass flow budget is ignored. We select $k$ to discount the effect of uncertainties and redundancies in

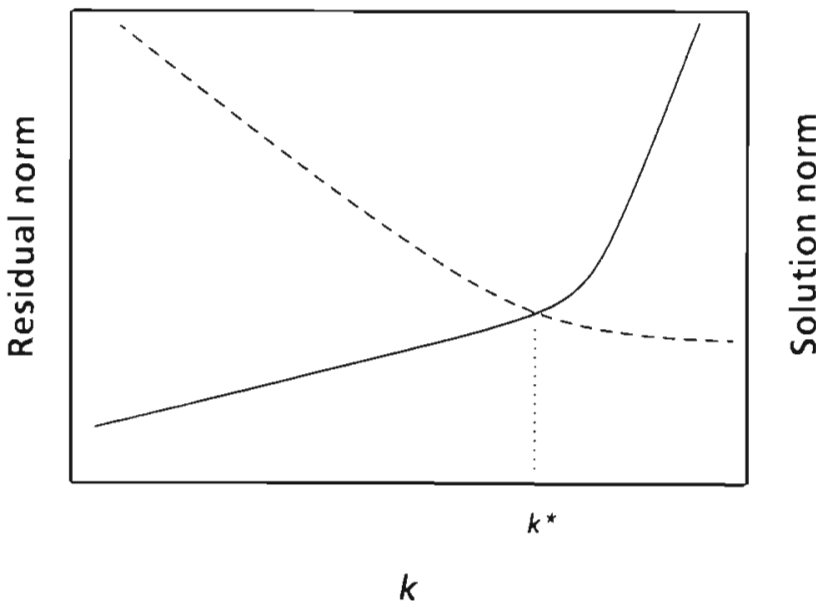

Fig. A.1. Schematic representation of the relationship between the complexity (solution norm, solid line) and the precision (residual norm, dashed line) of the solutions to a least-squares inverse problem and $k$, the number of linear combinations of the data used in computing the solutions. $k^{*}$ corresponds to the solution that best compromises between complexity and precision (see text for more details) 
the observational data while preserving the mass balance as much as possible.

Evaluating the solution. Information on the relative contributions of the mass balance equations to the inverse solution is contained in the resolution matrix of the observations or $U U^{\mathrm{T}}$ (Jackson 1972, Wiggins 1972, Wunsch 1978). Basically, $U U^{\top}$ expresses the relationship between the solution obtained from using all $m$ terms in the SVD of $A\left(r_{m}\right)$ and the actual least-squares solution:

$$
r=U U^{\top} r_{m}
$$

When $k=m, U U^{\mathrm{T}}$ is the identity matrix, i.e. the equations contribute fully and equally to the solution. For inconsistent equations, the diagonal elements vary from 0 to 1 and indicate the degree to which the associated equation adds independent information to the solution. We can also define a resolution matrix for the columns of $A, V V^{\mathrm{T}}$, analogous to that for the rows. Here, the diagonal elements give the extent to which each parameter is resolved independently of all the other parameters in the model.

The matrix $V V^{T}$ is the function that maps the food web observations into the parameter space to obtain the particular solution. Hence, the matrix $I-V V^{T}$ represents the part of the parameter space that is not fixed by the observations. The rationale behind the formula of Fu (1981) to compute the null space vectors (Eq. 15) is now clear: $I-V V^{\mathrm{T}}$ is used to scale columns of random numbers that are then orthogonalized to fill the null space.

Acknowledgements. We thank M. J. R. Fasham for his help during the development of our approach and $\mathrm{H}$. Ducklow for his comments on the manuscript.

\section{LITERATURE CITED}

Bannister, T. T. (1979). Quantitative description of steady state, nutrient-saturated algal growth, including adaptation. Limnol. Oceanogr. 24: 76-96

Banse, K. (1979). On weight dependence of net growth efficiency and specific respiration rates among field populations of invertebrates. Oecologia (Berl.) 38: 111-126

Beers, J. R. (1966). Studies on the chemical composition of the major zooplankton groups in the Sargasso Sea off Bermuda. Limnol. Oceanogr 11 520-528

Berman, M., Shahn, E., Weiss, M. F. (1962). The routine fitting of kinetic data to models: a mathematical formalism for digital computers. Biophys. J. 2: 275-287

Betzer, P. R., Showers, W. J., Laws, E. A., Winn, C. D., DiTullio, G. R., Kroopnick, M. (1984). Primary productivity and particle fluxes on a transect of the equator at $153^{\circ} \mathrm{W}$ in the Pacific Ocean. Deep Sea Res. 31. 1-11

Billen, G., Joiris, C., Wijnant, J., Gillain, G. (1980). Concentration and microbiological utilization of small organic molecules in the Scheldt estuary, the Belgian coastal zone of the North Sea and the English Channel. Estuar. coast. mar. Sci. $11279-294$
Bjørnsen, P. K. (1986). Bacterioplankton growth yield in continuous seawater cultures. Mar. Ecol. Prog. Ser. 30: 191-195

Blasco, D., Packard, T T., Garfield, P. C. (1982). Size dependence of growth rate, respiratory electron transport system activity, and chemical composition in marine diatoms in the laboratory. J. Phycol. 18: 58-63

Boak, A. C., Goulder, R. (1983). Bacterioplankton in the diet of the calanoid copepod Eurytemora sp. in the Humber estuary. Mar. Biol. 73: 139-149

Bolin, B., Björkström, A., Holmén, K., Moore, B. (1983). The simultaneous use of tracers for ocean circulation studies. Tellus 35B: 206-236

Bottrell, H. H., Robins, D. B. (1984). Seasonal variations in length, dry weight, carbon and nitrogen of Calanus helgolandicus from the Celtic Sea. Mar. Ecol. Prog. Ser. 14: 259-268

Brewer, P. G., Musgrave, D. L., Bradshaw, A. L. (1986). Reconciling carbon and oxygen signals in the upper ocean. In: U.S. Global Ocean Flux Study (GOFS) Report 3, U.S. GOFS Planning Office, Woods Hole, Mass., p. 124-130

Burris, J. E. (1980). Respiration and photorespiration in marine algae. In: Falkowski, P. G. (ed.) Primary productivity in the sea. Plenum Press, New York, p. 411-432

Calow, P. (1977). Conversion efficiencies in heterotrophic organisms. Biol. Rev. 52: 385-409

Caron, D. A., Goldman, J. C., Andersen, O. K., Dennett, M. R. (1985). Nutrient cycling in a microflagellate food chain: II. Population dynamics and carbon cycling. Mar. Ecol. Prog. Ser. 24: 243-254

Checkley, D. M. Jr, Entzeroth, L. C. (1985). Elemental and isotopic fractionation of carbon and nitrogen by marine, planktonic copepods and implications to the marine nitrogen cycle. J. Plankton Res. 7: 553-568

Coale, K. H., Bruland, K. W. (1987). Oceanic stratified euphotic zone as elucidated by ${ }^{234} \mathrm{Th}:{ }^{238} \mathrm{U}$ disequilibria. Limnol. Oceanogr. 32: 189-200

Conover, R. J. (1966). Factors affecting the assimilation of organic matter by zooplankton and the question of superfluous feeding. Limnol. Oceanogr. 11: 346-354

Conover, R. J. (1968). Zooplankton-life in a nutritionally dilute environment. Am. Zool. 8: 107-118

Conover, R. J. (1978). Feeding interactions in the pelagic zone. Rapp. P.-v. Réun. Cons. Int. Explor. Mer 173: 66-76

Conover, R. J., Corner, E. D. S. (1968). Respiration and nitrogen excretion by some marine zooplankton in relation to their life cycles. J. mar. biol. Ass. U.K. 48: 49-75

Copping, A. E., Lorenzen, C. J. (1980). Carbon budget of a marine phytoplankton-herbivore system with carbon-14 as a tracer. Limnol. Oceanogr. 25: 873-882

Corner, E. D. S., Cowey, C. B., Marshall, S. M. (1965). On the nutrition and metabolism of zooplankton. III. Nitrogen excretion. J. mar. biol. A.ss. U.K. 45: 429-442

Corner, E. D. S., Davies, A. G. (1971). Plankton as a factor in the nitrogen and phosphorus cycles in the sea. Adv. mar. Biol. 9: 101-204

Cox, J. L., Willason, S., Harding, L. (1983). Consequences of distributional heterogeneity of Calanus pacificus grazing. Bull. mar. Sci. 33: 213-226

Dagg, M. J. (1976). Complete carbon and nitrogen budgets for the carnivorous amphipod, Calliopius laevisculus (Kroyer). Int. Rev. ges. Hydrobiol. 61: 297-357

Draper, N. R., Smith, H. (1980). Applied regression analysis Wiley, New York

Droop, M. R., Scott, J. M. (1978). Steady-state energetics of a planktonic herbivore. J. mar. biol. Ass. U.K. 58: $749-772$ 
Ducklow, H., Purdie, D. A., Williams, P. J. LeB., Davies, J. M. (1986). Bacterioplankton: a sink for carbon in a coastal marine plankton community. Science 232: 865-867

Dugdale, R. C., Goering, J. J. (1967). Uptake of new and regenerated forms of nitrogen in primary productivity. Limnol. Oceanogr. 12: 196-206

Eppley, R. W., Peterson, B. J. (1979). Particulate organic matter flux and planktonic new production in the deep ocean. Nature, Lond. 282: 677-680

Enting, I. G. (1985). Principles of constrained inversion in the calibration of carbon cycle models. Tellus 37B: 7-27

Fasham, M. J. R. (1985). Flow analysis of materials in the marine euphotic zone. In: Ulanowicz, R. E., Platt, T. (eds.) Ecosystem theory for biological oceanography. Can. Bull. Fish. Aquat. Sci. 213: 139-162

Fenchel, $\Upsilon$ (1980). Suspension teeding in ciliated protozoa: feeding rates and their ecological significance. Microb. Ecol. 6: 13-25

Fenchel, T. (1982). Ecology of heterotrophic microflagellates. II. Bioenergetics and growth. Mar. Ecol. Prog. Ser. 8: 225-231

Fenchel, T., Harrison, P. (1976). The significance of bacterial grazing and mineral cycling for the decomposition of particulate detritus. In: Anderson, J. H., MacFayden, A. (eds.) The role of terrestrial and aquatic organisms in decomposition processes. Blackwell, Oxford, p. 285-299

Fenchel, T M., Jergensen, B. B. (1977). Detritus food chains of aquatic ecosystems: the role of bacteria. In: Alexander, $M$. (ed.) Advances in microbial ecology. Plenum Press, New York, p. 1-58

Field, J. G. (1972). Some observations on the release of dissolved organic carbon by the sea urchin, Strongylocentrotus droebachiensis. Limnol. Oceanogr. 17: 759-761

Finley, B. J., Uhlig, G. (1981). Calorific and carbon values of marine and freshwater Protozoa. Helgoländer Meeresunters. 34: 401-412

Fogg, G. E. (1983). The ecological significance of extracellular products of phytoplankton photosynthesis. Botanica mar 26: $3-14$

Fowler, S. W., Buat-Menard, P., Yokoyama, Y., Ballestra, S., Holm, E., Van Nguyen, H. (1987). Rapid removal of Chernobyl fallout from Mediteranean surface waters by biological activity, Nature, Lond. 329: 56-58

Frost, B. W. (1984). Utilization of phytoplankton production in the surface layer. In: Global Ocean Flux Study Workshop. National Academy of Sciences, Washington, D.C., p. 125-135

Fu, L.-L. (1981). General circulation and meridional heat transport of the subtropical south Atlantic determined by inverse methods. J. phys. Oceanogr. 11: 1171-1193

Gabbott, P. A., Holland, D. L. (1973). Growth and metabolism of Ostrea edulis larvae. Nature, Lond. 241:475-476

Gaudy, R., Boucher, J. (1983). Relation between respiration, excretion (ammonia and inorganic phosphorus) and activity of amylase and trypsin in different species of pelagic copepods from an Indian Ocean equatorial area. Mar. Biol. 75: $37-45$

Glibert, P. M. (1982). Regional studies of daily, seasonal and size fraction variability in ammonium remineralization. Mar. Biol. 70: 209-222

Goldman, J. C., Caron, D. A. (1985). Experimental studies on an omnivorous microflagellate: implications for grazing and nutrient regeneration in the marine microbial food chain. Deep Sea Res. 32: 899-915

Goldman, J. C., McCarthy, J. J., Peavey, D. G. (1979). Growth rate influence on the chemical composition of phytoplankton in oceanic waters. Nature, Lond. 279: 210-215
Hargrave, B. T. (1971). An energy budget for a depositfeeding amphipod. Limnol. Oceanogr. 16: 99-103

Harrison, W. G. (1980). Nutrient regeneration and primary production in the sea. In: Falkowski, P. G. (ed.) Primary productivity in the sea. Plenum Press, New York, p. $433-460$

Heinbokel, J. F. (1978). Studies on the functional role of tintinnids in the Southern California Bight. I. Grazing and growth rates in laboratory cultures. Mar. Biol. 47: 177-189

Hemmingsen, A. M. (1960). Energy metabolism as related to body size and respiratory surfaces, and its evolution. Reports of the Steno Memorial Hospital and Nordinsk Insulin Laboratorium 9: 6-110

Herbland, A. (1975). Utilisation par la flore hétérotrophe de la matière organique naturelle dans l'eau de mer. J. exp. mar. Biol. Ecol. 19: 19-31

Hirche, H.-J. (1983). Excretion and respiration of the Antarctic krill Euphausia superba. Polar Biol. 1: 205-209

Holligan, P. M., Harris, R. P., Newell, R. C., Harbour, D. S., Head, R. N., Linley, E. A. S., Lucas, M. I., Tranter, P. G. R., Weekley, C. M. (1984a). Vertical distribution and partitioning of organic carbon in mixed, frontal and stratified waters of the English Channel. Mar. Ecol. Prog. Ser. 14: 111-127

Holligan, P. M., Williams, P. J. LeB., Purdie, D., Harrís, R. P. (1984b). Photosynthesis, respiration and nitrogen supply of plankton populations in stratified, frontal and tidally mixed shelf waters. Mar. Ecol. Prog. Ser. 17: 201-213

Humphrey, G. F. (1975). The photosynthesis: respiration ratio of some unicellular algae. J. exp. mar. Biol. Ecol. 18: $111-119$

Ikeda, T (1974). Nutritional ecology of marine zooplankton. Mem. Fac. Hokkaido Univ. 22: 1-97

Ikeda, $T$ (1977). Feeding rates of planktonic copepods from a tropical sea. J. exp. mar. Biol. Ecol. 29: 263-277

Ikeda, T. (1985). Metabolic rates of epipelagic marine zooplankton as a function of body mass and temperature. Mar. Biol, 85: 1-11

Ikeda, T., Mitchell, A. W. (1982). Oxygen uptake, ammonia excretion and phosphate excretion by krill and other Antarctic zooplankton in relation to their body size and chemical composition. Mar. Biol. 71: 283-298

Intergovernmental Oceanographic Commission (1984). Ocean science for the year 2000. UNESCO, Paris

Isaacs, J. D. (1973). Potential trophic biomasses and trace substance concentration in unstructured marine foodwebs. Mar. Biol. 22: 97-104

Ituriaga, R., Hoppe, H.-G. (1977). Observations of heterotrophic activity on photoassimilated organic matter. Mar. Biol. 40: 101-108

Ivleva, I. V (1980). The dependence of crustacean respiration rate on body mass and habitat temperature. Int. Rev. ges. Hydrobiol. 65: 1-47

Jackson, D. D. (1972). Interpretation of inaccurate, insufficient and inconsistent data. Geophys. J. R. Astron. Soc. 28: 97-109

Jackson, D. D. (1985). A bayesian approach to nonlinear inversion. J. geophys. Res. 90: 581-591

Jackson, G. A., Williams, P. M. (1985). Importance of dissolved organic nitrogen and phosphorus to biological nutrient cycling. Deep Sea Res. 32: 223-235

Jenkins, W. J. (1982). Oxygen utilization rates in north Atlantic subtropical gyre and primary production in oligotrophic systems. Nature, Lond. 300: 246-248

Jenkins, W. J., Goldman, J. C. (1985). Seasonal oxygen cycling and primary production in the Sargasso Sea. J. mar. Res. 43: $465-491$ 
Jespersen, H., Olsen, K. (1982). Bioenergetics in veliger larvae of Mytilus edulis L. Ophelia 21.101-113

Joint, I. R., Morris, R. J. (1982). The role of bacteria in the turnover of organic matter in the sea. Oceanogr. mar. biol. A. Rev. 20: 65-118

Joint, I. R., Pomroy, A. J. (1983). Production of picoplankton and small nanoplankton in the Celtic Sea. Mar. Biol. 77 : $19-27$

Joint, I. R., Williams, R. (1985). Demands of the herbivore community on phytoplankton production in the Celtic Sea in August. Mar. Biol. 87: 297-306

King, K. R., Hollibaugh, J. T., Azam, F. (1980). Predator-prey interactions between the larvacean Oikopleura dioica and bacteria. Mar. Biol 56: 49-57

Knauer, G. A., Martin, J. H. (1981). Primary production and carbon-nitrogen fluxes in the upper $1500 \mathrm{~m}$ of the northeast Pacific. Limnol. Oceanogr. 26: 181-186

Knauer, G. A., Martin, J. H., Bruland, K. H. (1979). Fluxes of particulate carbon, nitrogen, and phosphorus in the upper water column of the northeast Pacific. Deep Sea Res. 26: $97-108$

Kofoed, L. H. (1975). The feeding biology of Hydrobia ventrosa (Montagu). II. Allocation of the components of the carbon-budget and the significance of the secretion of dissolved organic material. J. exp. mar. Biol. Ecol. 19: $243-256$

Kopylov, A. I., Moiseev, E. S. (1980). Effect of colorless flagellates on the determination of bacterial production in seawater. Dokl. Acad. Sci. U.S.S.R., Biol. Sec. 252: 272-274

Lampert, W. (1978). Release of dissolved organic carbon by grazing zooplankton. Limnol. Oceanogr. 23: 831-834

Lancelot, C., Billen, G. (1985). Carbon-nitrogen relationships in nutrient metabolism of coastal marine ecosystems. In: Jannasch, H. W., Williams, P. J. LeB. (eds.) Advances in aquatic microbiology, Vol. 3. Academic Press, London, p. $263-321$

Lanczos, C. (1961). Linear differential operators. Van Norstrand, Reinhold, New York

Lawson, C. L., Hanson, R. J. (1974). Solving least squares problems. Prentice-Hall, Englewood Cliffs, New Jersey

Leggett, W. C., Boynton, W. R., Gallucci, V. F., Johnson, L., Margalef, R., McGlade, J., Mikulecky, D., Rosen, R., Ulloa, R. O., Watson, J. (1985). I. Hypothesis testing and sampling design in exploited ecosystems. In: Ulanowicz, R. E., Platt, $\mathrm{T}$ (eds.) Ecosystem theory for biological oceanography. Can. Bull. Fish. Aquat. Sci. 213: 237-240

Mague, T. H., Friberg, E., Hughes, D. J., Morris, I. (1980). Extracellular release of carbon by marine phytoplankton; a physiological approach. Limnol. Oceanogr. 25: 262-279

Malone, T. C. (1980). Algal size. In: Morris, I. (ed.) The physiological ecology of the phytoplankton. Univ. Calif. Press, Berkeley, p. 433-463

McAllister, C. D. Shah, N., Strickland, J. D. H. (1964). Marine phytoplankton photosynthesis as a function of light intensity: a comparison of methods. J. Fish. Res. Bd Can. 21 $159-181$

Mullin, M. M., Brooks, E. R. (1976). Some consequences of distributional heterogeneity of phytoplankton and zooplankton. Limnol. Oceanogr. 21: $784-796$

Nash, J. C. (1979). Compact numerical methods of computers linear algebra and function minimization. Halstead Press, Bristol

National Science Foundation (1977). Ocean research in the 1980 s. Center for Ocean Management Studies, University of Rhode Island, Kingston, Rhode Island

Newell, R. C., Linley, E. A. S. (1984). Significance of microheterotrophs in the decomposition of phytoplankton estimates of carbon and nitrogen flow based on the biomass of plankton communities. Mar Ecol. Prog. Ser. 16 $105-119$

Newell, R. C., Lucas, M. I., Linley, E. A. S. (1981). Rate of degradation and efficiency of conversion of phytoplankton debris by marine microorganisms. Mar. Ecol. Prog. Ser 6 : 123-136

Nival, P., Malara, G., Charra, R., Palazzoli, I., Nival, S. (1974) Etude de la respiration et de l'excrétion de quelques copépodes planctoniques. J. exp. mar. Biol. Ecol. 15 231-260

Pace, M. L., Glasser, J. E., Pomeroy, L. R. (1984). A simulation analysis of continental shelf food webs. Mar. Biol. 82: $47-63$

Paffenhöfer, G. A., Knowles, S. C. (1979). Ecological implications of fecal pellet size, production and consumption by copepods. J. mar. Res. 37: 35-49

Parker, R. L. (1977). Understanding inverse theory. Ann. Rev. Earth Planet. Sci. 5: 35-64

Payne, W. J., Wiebe, W. J. (1978). Growth yield and efficiency in chemosynthetic microorganisms. Ann. Rev. Microbiol. 32: $155-183$

Platt, T., Conover, R. J. (1971). Variability and its effect on the 24 th chlorophyll budget of a small marine basin. Mar. Biol. 10: $52-65$

Platt, T., Denman, K. (1980). Patchiness in phytoplankton distribution. In: Morris, I. (ed.) The physiological ecology of the phytoplankton. Univ. of Calif. Press, Berkeley, p. $413-431$

Platt, T., Harrison, W. G. (1985). Biogenic fluxes of carbon and oxygen in the ocean. Nature, Lond. 318: 55-58

Platt, T., Lewis, M., Geider, R. (1984). Thermodynamics of the pelagic ecosystem: elementary closure conditions for biological production in the open ocean. In: Fasham, M. J. R. (ed.) Flows of energy and materials in marine ecosys. tems. Plenum Publishing, New York, p. 49-84

Platt, T., Mann, K. H., Ulanowicz, R. E. (1981). Mathematical models in biological oceanography. The Unesco Press, Paris

Pomeroy, L. R. (1974). The ocean's food web, a changing paradigm. Bioscience 24: 499-504

Pomeroy, L. R. (1984). A simulation analysis of continental shelf food webs. Mar. Biol. 82: 47-63

Pomeroy, L. R., Deibel, D. (1986). Temperature regulation of bacterial activity during the spring bloom in Newfoundland coastal waters. Science 233: 359-361

Poulet, S. A. (1983). Factors controlling utilization of non-algal diets by particle-grazing copepods. Oceanologica Acta 6 : 221-234

Rassoulzadegan, F. (1982). Dependence of grazing rate, gross growth efficiency and food size range on temperature in a pelagic oligotrichous ciliate Lohmanniella spiralis Leeg., fed on naturally occurring particulate matter. Ann. Inst. océanogr. Paris 58: 177-184

Raymont, J. E. G., Austin, J., Linford, E. (1964). Biochemical studies on marine zooplankton I. The biochemical composition of Neomysis integer. J. Cons. Int. Explor. Mer 28: 354-363

Robinson, J. D., Mann, K. H., Novitsky, J. A. (1982). Conversion of the particulate fraction of seaweed to bacterial biomass. Limnol. Oceanogr. 27: 1072-1079

Rodriguez, J., Mullin, M. M. (1986). Diel and interannual variation of size distribution of oceanic zooplankton biomass. Ecology 67: 215-222

Roman, M. R. (1984). Ingestion of detritus and microheterotrophs by pelagic marine zooplankton. Bull. mar Sci. 35: $477-494$ 
Ross, R. M. (1982). Energetics of Euphausia pacifica. I. Effects of body carbon and nitrogen. Mar. Biol. 68: 1-13

Scott, J. M. (1980). Effect of growth rate of the food alga on the growth/ingestion efficiency of a marine herbivore. J. mar. biol. Ass. U.K. 60 681-702

Seto, M., Tazaki, T. (1971). Carbon dynamics in the food chain system of glucose-Escherichia coli-Tetrahymena vorax. Jap. J. Ecol. 21. 179-187

Sheldon, R. W., Prakash, A., Sutcliffe, W. H. Jr (1972). The size distribution of particles in the ocean. Limnol. Oceanogr. 17 (3): $327-340$

Sherr, B. F., Sherr, E. B., Berman, T (1983). Grazing, growth, and ammonium excretion rates of a heterotrophic microflagellate fed with four species of bacteria. Appl environ. Microbiol. 45: 1196-1201

Sherr, E. B., Sherr, B. F., Fallon, R. D., Newell, S. Y. (1986). Small, alloricate ciliates as a major component of the marine heterotrophic nanoplankton. Limnol. Oceanogr. 31: $177-183$

Shulenburger, E., Reid, J. L. (1981). The Pacific shallow oxygen maximum, deep chlorophyll maximum, and primary productivity, reconsidered. Deep Sea Res. 28A: 901-919

Sieburth, J. McN., Smetacek, V., Lenz, J. (1978). Pelagic ecosystem structure: heterotrophic compartments of the plankton and their relationship to plankton size fractions. Limnol. Oceanogr. 23: 1256-1263

Small, L. F., Fowler, S. W., Moore, S. A., La Rosa, J. (1983) Dissolved and fecal pellet carbon and nitrogen release by zooplankton in tropical waters. Deep Sea Res. 30: 1199-1230

Smith, D. F. (1974). Quantitative analysis of the functional relationships existing between ecosystem components. Oecologia (Berl.) 16: 97-106

Smith, R. E. H., Geider, R. J., Platt, T. (1984). Microplankton productivity in the oligotrophic ocean. Nature, Lond. 311. $252-254$

Sorokin, Y I. (1981). Microheterotrophic organisms in marine ecosystems. In: Longhurst, A. R. (ed.) Analysis of marine ecosystems. Academic Press, London, p. 293-343

Steele, J. H., Frost, B. W. (1977). The structure of plankton communities. Phil. Trans. R. Soc. Lond. 280: 485-534

Steele, J. H. Henderson, E. W. (1981). A simple plankton model. Am. Nat. 117: 676-691

Stoecker, D. K. (1984). Particle production by planktonic ciliates. Limnol. Oceanogr. 29: 930-940
Tarantola, A., Valette, B. (1982). Generalized nonlinear inverse problems solved using the least-squares criterion. Rev. Geophys. Space Phys. 20: 219-232

Taylor, G. T., Iturriaga, R., Sullivan, C. W (1985). Interactions of bacterivorous grazers and heterotrophic bacteria with dissolved organic matter. Mar Ecol. Prog. Ser 23 129-141

Turner, J. T., Ferrante, J. G. (1979). Zooplankton fecal pellets in aquatic ecosystems. Bioscience 29: 670-677

Ulanowicz, R. E., Platt. T (eds.) (1985). Ecosystem theory for biological oceanography. Can. Bull. Fish. Aquat. Sci. 213

U.S. GOFS (1986). Global Ocean Flux Study: Report 3. U.S. GOFS Planning Office, Woods Hole, Mass.

Van Es, F. B., Meyer-Reil, L.-A. (1982). Biomass and metabolic activity of heterotrophic marine bacteria. In: Marshall, K. C. (ed.) Advances in microbial ecology. Plenum Press, New York, p. 111-170

Vézina, A. F., Platt, T. (1987). Small-scale variability of new production and particulate fluxes in the ocean. Can. J. Fish. Aquat. Sci 44: 198-205

Vidal, J. (1980). Physioecology of zooplankton. III. Effects of phytoplankton concentration, temperature and body size on the metabolic rate of Calanus pacificus. Mar Biol. 56: 195-202

Wang, R., Conover, R. J. (1986). Dynamics of gut pigment in the copepod Temora longicornis and the determination of in situ grazing rates. Limnol. Oceanogr. 31: 867-877

Wiggins, R. A. (1972). The general linear inverse problem: implication of surface waves and free oscillations for earth structure. Rev. Geophys. Space Phys. 10: 251-285

Williams, P. J. LeB. (1975). Biological and chemical aspects of dissolved organic material in sea water. In: Riley, J. P., Skirrow, G. (eds.) Chemical oceanography. Academic Press, London, p. 301-363

Williams, P. J. LeB., Heinemann, K. R., Marra, J., Purdie, D. A. (1983). Comparison of ${ }^{14} \mathrm{C}$ and $\mathrm{O}_{2}$ measurements of phytoplankton production in oligotrophic waters. Nature, Lond. 305: $49-50$

Wunsch, C. (1978). The north Atlantic general circulation west of $50^{\circ} \mathrm{W}$ determined by inverse methods. Rev. Geophys. Space Phys, 16: 583-620

Wunsch, C., Minster, J.-F. (1982). Methods for box models and ocean circulation tracers: mathematical programming and nonlinear inverse theory. J. geophys. Res. 87: 5647-5662 